\title{
Effect of Foliar Application of Some Nutrients on "Le-Conte" Pear Trees Grown under Calcareous Soil Conditions
}

\author{
Nagwa A. Abd-Elmegeed, Wesam A. Nabeel and Magda \\ M. Nasr \\ Horticulture Research Institute, Agricultural Research Centre, \\ Cairo, Egypt.
}

\begin{abstract}
7 HIS INVESTIGATION was carried out during two 1 successive seasons (2010 and 2011) on "Le-Conte" pear trees (Pyrus communis X Pyrus pyrifolia). The trees were 8 years old, budded on Pyrus communis rootstock and grown on calcareous soil under flood irrigation system in a private orchard located at Borg ElArab region, Alexandria governorate. Twenty-four trees planted at $5 \mathrm{x}$ $5 \mathrm{~m}$ apart were selected as uniform as possible. The experiment involved the following six treatments: Control (untreated trees), Potassium sulphate at $0.1 \%$, Copper sulphate at $0.02 \%$, Sequestrated zinc at $0.04 \%$, Sequestrated iron at $0.06 \%$ and Mixed nutrients mixed by the same concentration. Each treatment was applied three times during the growing season starting immediately after fruit set and at 21 days intervals.
\end{abstract}

The results showed that all treatments gave better results compared with control. Mixed nutritions gave the highest results in this trend. This treatment resulted in the best vegetative growth parameters. Leaf $\mathrm{K}, \mathrm{Cu}, \mathrm{Zn}$ and $\mathrm{Fe}$ content were also improved, in addition to ensure the highest yield, improved the physical and chemical characteristics of fruits.

"Le-conte" is the main pear cultivar, widely grown in Egypt grafted on the main rootstock, $P$. communis that shows high susceptibility to pear blights (Reimer, 1950). In the last 20 year, the pear cultivated area in Egypt decreased from 14923 feddans in 1995 to 10616 feddans in 2012 (Egyptian Ministry of Agriculture Statistics).

Calcareous soil contains high percentage of $\mathrm{CaCO}_{3}$ and a high $\mathrm{pH}$ value that cause a precipitation of $\mathrm{Fe}, \mathrm{Mn}$ and $\mathrm{Zn}$ in an unavailable form for plants. Thus foliar applications seem to be valuable for correcting the widespread occurrence of certain micronutrient deficiency symptoms (Marschner, 1995 and Taiz and Zieger, 1998). Essential elements either as macro or micro-nutrients play a vital role in growth and productivity of fruit crops. Several investigators have demonstrated the role of potassium in growth (Semenovich and Salmina, 1979 and Delcheva and Makariev, 1982), yield (Mantinger, 1983) and fruit quality (Ljones, 1974 and Yogaratnam and Johnson, 1982). 
The occurrence of adequate nutrition of plants with micronutrient cations $\mathrm{Cu}$, $\mathrm{Mn}, \mathrm{Zn}$, and Fe depends on several factors. The ability of soil to supply plant roots with these nutrients, mobility and translocation of these within the plant and the interaction between micronutrients themselves as with some macro-nutrients like phosphorus, whether in soil and/or the plants; are factors governing nutrients balance in the plants (Amer et al., 2010). Furthermore, soil applied micronutrients increased their concentrations in leaves and fruits of Ber tree more than foliar application except $\mathrm{Cu}$ (Amer et al., 2010).

The foliar application of micronutrients has become in wide use to correct the problem of micronutrients deficiency in many fruit crops. Although micronutrients are needed in relatively small quantities for adequate plant growth and production, their deficiencies cause a great disturbance in the physiological and metabolic processes involved in the plant as a result of foliar application of chelated iron and zinc on "Thompson Seedless" grapes (El-Gazzar at al., 1979). Microelements problems have increasing importance in Egypt not only in calcareous soil at the newly reclaimed areas but also in alluvial soil in the Nile Delta as a result of high microelements swallowed by several crops per year (Amberger, 1982).

Some work has been carried out in Egypt concerning the effect of microelements spray on deciduous fruits (Awad and Atawia, 1995; Kabeel et al., 1998, Gobara 1998 on pear, El-Shazly 1999, El-Shobaky et al., 2001 and Naiema 2006). Also, El-Seginy et al. (2003) reported that, foliar application of "Anna" apple trees with a mixture of chelated $(\mathrm{Fe}, \mathrm{Zn}$ and $\mathrm{Mn}$ ) is recommended to increase fruit set, yield quantity and fruit quality of trees grown on calcareous soil. Moreover, Sayed et al. (2013) found that, phosphorus and copper have an antagonistic impact on zinc.

Therefore, the main objective of this study was to study the effect of foliar application of some nutrients on "Le-Conte" pear trees grown under calcareous soil conditions.

\section{Material and Method}

This investigation was carried out during two successive seasons of 2010 and 2011 on "Le-Conte" pear trees (Pyrus communis X Pyrus pyrifolia). The trees were 8 years old, budded on Pyrus communis rootstock and grown on calcareous soil under flood irrigation system in a private orchard located at Borg El-Arab region, Alexandria governorate. Some physical and chemical analysis of this experimental soil is illustrated in Table 1.

Egypt. J. Hort. Vol. 40, No.2 (2013) 
TABLE 1. Physical and chemical characters of experimental orchard soil.

\begin{tabular}{|l|c|c|c|}
\hline \multicolumn{1}{|c|}{ Clay (\%) } & $\mathbf{1 7 . 5}$ & $\mathbf{C a C O}_{\mathbf{3}}(\mathbf{m e q} / \mathbf{L})$ & $\mathbf{2 0 . 2 6}$ \\
\hline Silt (\%) & 12.5 & $\mathrm{Ca}^{++}(\mathrm{meq} / \mathrm{L})$ & 6.35 \\
\hline Sand $(\%)$ & 70 & $\mathrm{Mg}^{++}(\mathrm{ppm})$ & 3.81 \\
\hline Texture & Sandy loam & $\mathrm{Na}^{+}(\mathrm{ppm})$ & 6.087 \\
\hline EC (Ds/m) & 0.761 & $\mathrm{~K}^{+}(\%)$ & 0.513 \\
\hline Organic matter \% & 3.76 & $\mathrm{Cl}^{-}(\mathrm{ppm})$ & 5.5 \\
\hline Co3- and HCO3- (meq/L) & 17.27 & $\mathrm{So}_{4}{ }^{-}(\mathrm{ppm})$ & 4.1 \\
\hline Available P (meq/L) & 37.76 & $\mathrm{Total} \mathrm{N}^{+}(\mathrm{ppm})$ & 7.1 \\
\hline pH & 7.6 & $\mathrm{~B}(\mathrm{ppm})$ & 1.539 \\
\hline
\end{tabular}

Twenty-four trees ( 5 x $5 \mathrm{~m}$ apart) as uniform as possible were selected for this study. The trees received the cultural practices that are recommended by Ministry of Agriculture. Complete randomized block design was applied. The experiment involved the following six treatments:

- Control.

- Potassium sulphate at $0.10 \%$.

- Copper sulphate at $0.02 \%$.

- Sequestrated zinc at $0.04 \%$.

- $\quad$ Sequestrated iron at $0.06 \%$.

- All the studied nutrients mixed by the same concentrations.

Each treatment was replicated four times, one tree per each. The previous four compounds were applied three times during the growing season starting immediately after fruit set and at 21 days intervals. Triton B was added as wetting agent to all spraying solutions at $0.1 \%$.

Samples of twenty leaves from the middle part of the shoots according to Chuntanaperb and Cummings (1981) were selected at random from each replicate (last week of August) to determine their contents of $\mathrm{K}, \mathrm{Cu}, \mathrm{Zn}$ and $\mathrm{Fe}$ according to Wilde et al. (1985). Leaf samples were washed and oven dried at 70 $\mathrm{C}$ to constant weight and then ground. Determinations of the leaf content of the above mentioned nutrients were carried out on dry weight basis.

Four main branches as similar as possible were chosen at the four cardinal points of each treated tree, tagged and the average of the current shoots per selected branch were counted, their length and diameter were measured as $(\mathrm{cm})$ on mid October. Leaf area was determined using leaf area meter (Model CI-203, CID, Inc., U.S.A.). Fruits were collected at maturity stage (late August) and yield was recorded as weight in $\mathrm{Kg}$.

\section{Physical properties}

Fruit weight $(\mathrm{g})$, dimensions $(\mathrm{cm})$ and fruit firmness was estimated by Magness and Taylor (1925) pressure tester which has a standard 5/16 of inch plunger and recorded as $\mathrm{lb} / \mathrm{inch}^{2}$. 


\section{Chemical properties}

TSS (\%) was determined by ATAGO hand refractometer, acidity (\%) (as malic acid) according to A.O.A.C. (1992), total sugars (\%) contents according to Malik and Singh (1980) and reducing sugars (\%) by Nelson arsenatemdybdate colorimetric method (Dubois, et al., 1956). Non-reducing sugar (\%) were calculated by the difference between total sugars and reducing sugars.

Regression equations as well as correlation coefficient were assessed between shoot length and fruit yield and juice total sugars.

Data obtained were statistically analyzed using the analysis of variance method reported by Snedecor and Cochran (1990) and the differences were tested by L.S.D. at $5 \%$ level.

\section{Results and Discussion}

\section{Foliage characters}

Vegetative growth

Concerning shoot length and diameter, results of Table 2 illustrate that, Mixed treatments significantly increased the length and diameter of pear shoots. Moreover, mixed nutrients resulted in the longest $(59.00 \mathrm{~cm})$ and widest $(1.23 \mathrm{~cm})$ shoots. However, iron spray at $0.06 \%$ followed that treatment on the shoots length and width. Also, all treatments significantly increased leaf area compared with control. The highest area was due to mixed compound $\left(30.53\right.$ and $\left.31.41 \mathrm{~cm}^{2}\right)$ in both seasons, respectively, then the effect of zinc at $0.04 \%$ (28.48 and $\left.29.07 \mathrm{~cm}^{2}\right)$.

However, this increment presented as a result of foliar application of micronutrients may be attributed to their effect on formation of carbohydrates and proteins as well as to the effect of $\mathrm{Zn}$ on building up the natural auxin IAA and consequently activation of cell division process in plant tissues (Nijjar 1985). Iron spray was effective of increasing pear vegetative growth. Larue and Johnson (1989) stated that, foliar fertilizers as chelate should be easily absorbed by the plants and rapidly transported and should be easily release their ions to affect the plant of peach, plum and nectarine. Pear trees suffer from colorosis on calcareous soil and iron can greatly correct this phenomenon (Westwood, 1993).

In addition, spraying nutrients i.e. $\mathrm{B}, \mathrm{Zn}, \mathrm{K}$, and $\mathrm{S}$ were appeared for improving growth and productivity of "Anna" apple trees (Ahmed et al., 1997). However, the same results were reported by Ubavic et al. (1984) on apple, Chekan (1988) and Mohamed and Ahmed (1991) on "Anna" apple, Naiema (2006) on pear, El-Khawaga (2007) on olive and El-Sisy (2011) on guava trees.

Egypt. J. Hort. Vol. 40, No.2 (2013) 
TABLE 2. Effect of foliar application of some nutrients on some vegetative growth parameters of "Le-Conte" pear trees during 2010 and 2011 seasons.

\begin{tabular}{|l|c|c|c|c|c|c|}
\hline \multirow{2}{*}{ Treatments } & \multicolumn{2}{|c|}{$\begin{array}{c}\text { Shoot length } \\
(\mathbf{c m})\end{array}$} & $\begin{array}{c}\text { Shoot diameter } \\
(\mathbf{c m})\end{array}$ & \multicolumn{2}{c|}{$\begin{array}{c}\text { Leaf area } \\
(\mathbf{c m})\end{array}$} \\
\cline { 2 - 7 } & $\mathbf{2 0 1 0}$ & $\mathbf{2 0 1 1}$ & $\mathbf{2 0 1 0}$ & $\mathbf{2 0 1 1}$ & $\mathbf{2 0 1 0}$ & $\mathbf{2 0 1 1}$ \\
\hline Control (untreated trees) & 45.18 & 44.38 & 0.87 & 0.86 & 23.98 & 23.67 \\
\hline Potassium sulphate at 0.1\% & 50.83 & 49.97 & 1.00 & 1.03 & 27.51 & 27.81 \\
\hline Copper sulphate at $0.02 \%$ & 49.81 & 48.42 & 0.96 & 0.94 & 26.21 & 27.77 \\
\hline Sequestrated zinc at $0.04 \%$ & 51.70 & 52.58 & 1.01 & 1.00 & 28.48 & 29.07 \\
\hline Sequestrated iron at $0.06 \%$ & 54.39 & 54.17 & 1.18 & 1.15 & 27.04 & 28.29 \\
\hline Mixed nutrients & 59.00 & 57.77 & 1.23 & 1.22 & 30.53 & 31.41 \\
\hline L.S.D. at 0.05 & 1.65 & 1.89 & 0.03 & 0.05 & 0.84 & 0.96 \\
\hline
\end{tabular}

\section{Chemical analysis}

The effect of treatments on leaf $K, \mathrm{Cu}, \mathrm{Zn}$ and Fe content

Data in Table 3 cleared that all treatments increased leaf content of $\mathrm{K}, \mathrm{Cu}$, $\mathrm{Zn}$ and $\mathrm{Fe}$ compared to control. Moreover, treatment of mixed nutrients resulted in the highest values significantly $(1.39$ and $1.45 \% \mathrm{~K} ; 17$ and $18 \mathrm{ppm}$ $\mathrm{Cu}, 38$ and $40 \mathrm{ppm} \mathrm{Zn}$ and 138 and $139 \mathrm{ppm} \mathrm{Fe}$ ) in both seasons respectively. The same results were reported by Sarma and Bhattacharyya (1989) and El-Sisy (2011) on guava, Raesa et al., Mohamed and Ahmed (1991), Sourour (1992), Kabeel et al. (1998) and El-Segin and Khalil (2000) on pear, El-Shazly (1999) and El-Segin (2003) on apple and Abd-Ella and El-Sisy (2006) on fig. The increase of plant nutrient status resulted from spraying different solutions may be attributed to quick absorption via leaves and the limited loss of the nutrients when they were sprayed (Marschner, 1995).

Metabolism of plant hormones such as auxin (IAA) and tryptophan decrease in zinc deficiency condition, as a result of leaf growth withdraw. In fact, zinc is essential for tryptophan synthesis, which is a prerequisite for auxin formation, therefore amount of auxin decreases by zinc deficiency (Marschner, 1995 and Pedler et al., 2000). Zinc is the main building part of some enzymes and is needed for the plant enzymes formation of most species. In addition, many enzymatic reactions be active by zinc (Vitosh $e$ t al., 1994, Pedler et al., 2000 and Akay, 2011). 
TABLE 3. Effect of foliar application of some nutrients on leaf macro and micro elements contents (\% and ppm dry weight, respectively) of "Le-Conte" pear trees during 2010 and 2011 seasons.

\begin{tabular}{|l|c|c|c|c|c|c|c|c|}
\hline \multirow{2}{*}{ Treatments } & \multicolumn{2}{|c|}{ K (\%) } & \multicolumn{2}{c|}{ Cu (ppm) } & \multicolumn{2}{c|}{ Zn (ppm) } & \multicolumn{2}{c|}{ Fe (ppm) } \\
\cline { 2 - 10 } & $\mathbf{2 0 1 0}$ & $\mathbf{2 0 1 1}$ & $\mathbf{2 0 1 0}$ & $\mathbf{2 0 1 1}$ & $\mathbf{2 0 1 0}$ & $\mathbf{2 0 1 1}$ & $\mathbf{2 0 1 0}$ & $\mathbf{2 0 1 1}$ \\
\hline Control (untreated trees) & 1.00 & 0.98 & 10 & 11 & 19 & 20 & 109 & 108 \\
\hline Potassium sulphate at 0.1\% & 1.37 & 1.35 & 12 & 13 & 26 & 27 & 116 & 114 \\
\hline Copper sulphate at 0.02\% & 1.06 & 1.03 & 15 & 17 & 24 & 26 & 113 & 112 \\
\hline Sequestrated zinc at 0.04\% & 1.02 & 1.01 & 11 & 12 & 32 & 33 & 114 & 113 \\
\hline Sequestrated iron at 0.06\% & 1.07 & 1.04 & 13 & 13 & 29 & 28 & 125 & 128 \\
\hline Mixed nutrients & 1.39 & 1.45 & 17 & 18 & 38 & 40 & 138 & 139 \\
\hline L.S.D. at 0.05 & 0.06 & 0.08 & 1.36 & 1.24 & 1.15 & 1.21 & 2.25 & 2.16 \\
\hline
\end{tabular}

\section{Fruit characteristics}

Yield

Data presented in Table 4 demonstrate the effect of conducted treatments on the pear tree yield (Kg.).

TABLE 4. Effect of foliar application of some nutrients on yield, some physical parameters and firmness of "Le-Conte" pear trees during 2010 and 2011 seasons.

\begin{tabular}{|c|c|c|c|c|c|c|c|c|c|c|}
\hline \multirow{2}{*}{ Treatments } & \multicolumn{2}{|c|}{$\begin{array}{c}\text { Yield } \\
\text { (Kg/tree) }\end{array}$} & \multicolumn{2}{c|}{$\begin{array}{c}\text { Fruit } \\
\text { weight } \\
\text { (g) }\end{array}$} & \multicolumn{2}{c|}{$\begin{array}{c}\text { Fruit } \\
\text { length } \\
\text { (cm) }\end{array}$} & \multicolumn{2}{c|}{$\begin{array}{c}\text { Fruit } \\
\text { diameter } \\
(\mathbf{c m})\end{array}$} & \multicolumn{2}{c|}{$\begin{array}{c}\text { Fruit } \\
\text { firmness } \\
\text { (lb/Inch }\end{array}$} \\
\cline { 2 - 13 } & $\mathbf{2 0 1 0}$ & $\mathbf{2 0 1 1}$ & $\mathbf{2 0 1 0}$ & $\mathbf{2 0 1 1}$ & $\mathbf{2 0 1 0}$ & $\mathbf{2 0 1 1}$ & $\mathbf{2 0 1 0}$ & $\mathbf{2 0 1 1}$ & $\mathbf{2 0 1 0}$ & $\mathbf{2 0 1 1}$ \\
\hline $\begin{array}{c}\text { Control } \\
\text { (untreated trees) }\end{array}$ & 38.80 & 39.29 & 156.05 & 161.68 & 7.97 & 8.02 & 6.68 & 6.82 & 12.45 & 12.75 \\
\hline $\begin{array}{c}\text { Potassium } \\
\text { sulphate at 0.1\% }\end{array}$ & 44.08 & 45.46 & 196.38 & 199.57 & 8.85 & 8.91 & 7.33 & 7.35 & 12.34 & 12.63 \\
\hline $\begin{array}{c}\text { Copper } \\
\text { sulphate at } \\
0.02 \%\end{array}$ & 41.70 & 40.61 & 164.81 & 173.72 & 8.25 & 8.45 & 7.04 & 7.08 & 12.44 & 12.75 \\
\hline $\begin{array}{c}\text { Sequestrated } \\
\text { zinc at 0.04\% }\end{array}$ & 41.74 & 41.94 & 175.72 & 185.12 & 8.43 & 8.56 & 7.07 & 7.16 & 12.50 & 12.78 \\
\hline $\begin{array}{c}\text { Sequestrated } \\
\text { iron at 0.06\% }\end{array}$ & 46.51 & 46.31 & 187.14 & 200.66 & 8.54 & 8.72 & 7.23 & 7.43 & 12.52 & 12.81 \\
\hline Mixed nutrients & 57.18 & 58.23 & 221.54 & 210.19 & 8.95 & 8.89 & 7.68 & 7.95 & 12.77 & 13.06 \\
\hline L.S.D. at 0.05 & 2.48 & 2.27 & 3.52 & 3.61 & 0.09 & 0.08 & 0.06 & 0.05 & 0.37 & 0.41 \\
\hline
\end{tabular}

All studied treatments increased the yield compared with control. However, this result was statically confirmed except copper sulphate in $2^{\text {nd }}$ season.

Egypt. J. Hort. Vol. 40, No.2 (2013) 
Mixed nutrients resulted in significantly the highest yield (57.18 and 58.33 $\mathrm{Kg} /$ tree in both seasons respectively) compared to the remaining treatments and control. Sequestrated iron at $0.06 \%$ followed $(46.51$ and $46.31 \mathrm{Kg} /$ tree) then potassium sulphate at $0.1 \%$ (44.08 and $45.46 \mathrm{Kg} /$ tree $)$ in this respect with significant differences.

Fe had an important function in enzymatic systems and chlorophyll formation and consequently increased photosynthesis which finally increased the yield (Smith 1957). However, the improvement of yield as a result of $\mathrm{Zn}$ sprays may be explained by the fact that $\mathrm{Zn}$ plays a role in tryptophan synthesis which is the precursor of endogenous natural hormone (IAA) which is necessary for all plant metabolic processes (Price 1970). Although foliar sprays are more effective, foliar-absorbed $\mathrm{Zn}$ is not easily translocated in plants which necessitates repeated spray application (Swietlik 2002).

Zinc is essential micronutrient for proteins production in plant; also, zinc is the main composition of ribosome and essential for their development. Amino acids accumulated in plant tissues and protein synthesis decline by zinc deficit. One of the sites of protein synthesis is pollen tubes that amount of zinc in their tip is 150 micrograms per gram of dry matter. In addition, zinc will contribute on the pollination by impact on pollen tube formation (Marschner, 1995; Outten and O'Halloran, 2001 and Pandey et al., 2006).

These results were in line with those obtained by EL-Gazzar et al. (1979) on grapes, Yogarotnam and Johnson (1982), Dasham and Ali (1986) and El-Sisy (2011) on guava, Kilany and Kilany (1991) and El-Seginy et al. (2003) on apple and Datir et al. (2012) on "Chilli".

\section{Physical fruit characters}

Average fruit weight

Data in Table 4 present the effect of conducted treatments on the average fruit weight in both seasons of the investigation. Significant enhancements were dedicated to conducted treatments compared with control in both seasons. Mixed nutrients induced significantly the highest average fruit weight (221.54 and $210.19 \mathrm{gm})$ followed by iron at $0.06 \%$ (187.14 and $200.66 \mathrm{gm})$ then $\mathrm{K}$ at $0.1 \%$ (196.38 and $199.57 \mathrm{gm})$ for both seasons, respectively compared with the remaining treatments.

These findings disagreed with El-Safty et al. (1998) on citrus, El-Shazly (1999) on apple, Amer et al. (2010) on ber fruit who found that fruit weight wasn't affected neither by increasing rate of applied micronutrients nor by method of application, while, EL-Sisy (2011) found that the best results associated with the high rate of mixture $(\mathrm{Fe}+\mathrm{Mn}+\mathrm{Zn})$ at $3000 \mathrm{ppm}$ either foliar or soil application in form chelate or sulphate twice annually on guava trees. 


\section{Fruit length and diameter}

Data in Table 4 illustrate the effect of applied treatments on both fruit length and diameter respectively. It is evident that all considered treatments resulted in significant increases in both parameters compared with control in both seasons. The effect of mixed nutrients was markedly the utmost compared with control and remaining treatments.

These results were partially agreed with Awad and Atawia (1995) and ElShazly (1999) on apple. However, the results of this study are in harmony with those reported by El-Seginy and Khalil (2000) on pear, Abd-Ella and El-Sisy (2006) on fig, Amer et al. (2010) on ber fruit and El-Sisy (2011) on guava fruits.

\section{Fruit firmness (Ib/inch $\left.{ }^{2}\right)$}

Data tabulated in Table 4 show the effect of conducted treatments on the fruit firmness $\left(\mathrm{Ib} / \mathrm{inch}^{2}\right)$ compared with control. Fruit firmness was insignificantly affected by the majority of conducted treatments. Mixed nutrients, sequestrated Iron at $0.06 \%$ and copper sulphate at $0.02 \%$ treatments increased this parameter insignificantly compared with control and with differences between them in both seasons.

The obtained results agreed with those reported by El-Sisy (2011) on guava fruits.

\section{Chemical fruit characters}

Juice total soluble solids percentage (TSS \%): Data in Table 5 illustrate the effect of considered treatments on the average juice TSS\%. Data clarify that juice of control fruits attained the least TSS\% amounting to (12.57 and $12.43 \%$ in both seasons respectively). All treatments increased this parameter compared with control in both seasons. Significantly the highest effect was due to mixed nutrients treatment in both seasons (14.80 and 14.77\%) and potassium sulphate at $0.1 \%$ treatment followed (14.43 and $14.77 \%)$.

TABLE 5. Effect of foliar application of some nutrients on some fruit quality of "LeConte" pear trees during 2010 and 2011 seasons.

\begin{tabular}{|l|c|c|c|c|c|c|}
\hline \multirow{2}{*}{ Treatments } & \multicolumn{2}{c|}{$\begin{array}{c}\text { T.S.S. } \\
(\mathbf{\%})\end{array}$} & \multicolumn{2}{c|}{$\begin{array}{c}\text { Acidity } \\
(\boldsymbol{\%})\end{array}$} & \multicolumn{2}{c|}{$\begin{array}{c}\text { T.S.S./acid } \\
\text { ratio }\end{array}$} \\
\cline { 2 - 7 } & $\mathbf{2 0 1 0}$ & $\mathbf{2 0 1 1}$ & $\mathbf{2 0 1 0}$ & $\mathbf{2 0 1 1}$ & $\mathbf{2 0 1 0}$ & $\mathbf{2 0 1 1}$ \\
\hline Control (untreated trees) & 12.57 & 12.43 & 0.40 & 0.41 & 31.43 & 30.32 \\
\hline Potassium sulphate at $0.1 \%$ & 14.43 & 14.77 & 0.29 & 0.32 & 50.19 & 44.85 \\
\hline Copper sulphate at $0.02 \%$ & 13.63 & 13.83 & 0.34 & 0.38 & 39.83 & 36.76 \\
\hline Sequestrated zinc at $0.04 \%$ & 13.70 & 13.63 & 0.36 & 0.35 & 37.41 & 39.45 \\
\hline Sequestrated iron at $0.06 \%$ & 14.07 & 13.87 & 0.34 & 0.32 & 41.84 & 42.94 \\
\hline Mixed nutrients & 14.80 & 14.77 & 0.27 & 0.31 & 55.30 & 47.68 \\
\hline L.S.D. at 0.05 & 1.31 & 1.48 & 0.03 & 0.04 & 2.73 & 2.64 \\
\hline
\end{tabular}

Egypt. J. Hort. Vol. 40, No.2 (2013) 
Juice acidity percentage: Data in Table 5 present the effect of conducted treatments on the juice acidity percentage compared with control; juice acidity was significantly decreased by all of the conducted treatments in the both seasons. Mixed nutrients were the lowest percentage in this respect $(0.27$ and $0.31 \%)$ in both seasons respectively. Potassium sulphate at $0.1 \%$ was followed $(0.29$ and $0.32 \%)$.

The obtained results were partially agreed with those reported by Mohamed and Ahmed (1991) on "Anna" apple who found a reduction in total acidity in fruit pulp due to fertilization, while El-Sisy (2011) reported that there was no significant effect in fruit acidity percent due to all treatments in both seasons of study, but there was a slight decrease in acidity due to all treatments fertilization on guava.

TSS/acid (ratio): Data in Table 5 indicated that all treatments increased significantly the ratio of TSS\% to acidity \% compared with control in both seasons. Mixed nutrients treatment was the highest value (55.30 and 47.68\%) in both seasons. Potassium sulphate at $0.1 \%$ treatment followed (50.19 and 44.85 in both seasons respectively).

Mohamed and Ahmed (1991) found that applying the three elements together $(\mathrm{Cu}$ $+\mathrm{Zn}+\mathrm{Fe})$ at the higher rate was also accompanied with improve in total soluble solids in apple trees. Also, Ahmed et al. (1997) and El-Sisy (2011) found the same trend.

Fruit $\mathrm{K}, \mathrm{Cu}, \mathrm{Zn}$ and $\mathrm{Fe}$ content: Concerning the effect of foliar application of some nutrients on fruit potassium $(\mathrm{K})$ content, data of Table 6 cleared that all treatments significantly increased $\mathrm{K} \%$ content compared with control. Mixed nutrients treatment induced significantly the highest percentages in both seasons amounting to (1.19 and $1.24 \%$ respectively). Results due to potassium sulphate $0.1 \%$ treatment followed (1.13 and $1.17 \%)$. Whereas, control fruit potassium content was the least amounting to 0.88 and $0.87 \%$ in both seasons respectively.

TABLE 6. Effect of foliar application of some nutrients on fruit macro and micro elements contents of "Le-Conte" pear trees during 2010 and 2011 seasons.

\begin{tabular}{|l|c|c|c|c|c|c|c|c|}
\hline \multirow{2}{*}{\multicolumn{1}{c|}{ Treatments }} & \multicolumn{2}{|c|}{ K (\%) } & \multicolumn{2}{c|}{ Cu (ppm) } & \multicolumn{2}{c|}{ Zn (ppm) } & \multicolumn{2}{c|}{ Fe (ppm) } \\
\cline { 2 - 11 } & $\mathbf{2 0 1 0}$ & $\mathbf{2 0 1 1}$ & $\mathbf{2 0 1 0}$ & $\mathbf{2 0 1 1}$ & $\mathbf{2 0 1 0}$ & $\mathbf{2 0 1 1}$ & $\mathbf{2 0 1 0}$ & $\mathbf{2 0 1 1}$ \\
\hline Control (untreated trees) & 0.88 & 0.87 & 7 & 8 & 12 & 11 & 85 & 86 \\
\hline Potassium sulphate at 0.1\% & 1.13 & 1.17 & 10 & 10 & 14 & 13 & 91 & 88 \\
\hline Copper sulphate at 0.02\% & 0.96 & 0.95 & 13 & 12 & 15 & 16 & 92 & 90 \\
\hline Sequestrated zinc at 0.04\% & 0.95 & 0.94 & 9 & 10 & 21 & 20 & 87 & 86 \\
\hline Sequestrated iron at 0.06\% & 0.96 & 0.92 & 11 & 10 & 21 & 19 & 96 & 97 \\
\hline Mixed nutrients Together & 1.19 & 1.24 & 15 & 14 & 23 & 24 & 101 & 102 \\
\hline L.S.D. at 0.05 & 0.05 & 0.04 & 1.11 & 1.13 & 1.15 & 1.17 & 2.28 & 2.53 \\
\hline
\end{tabular}

Egypt. J. Hort. Vol. 40, No.2 (2013) 
Micronutrients in fruits $(\mathrm{Cu}, \mathrm{Zn}$ and $\mathrm{Fe})$ in Table 6 show that there was a significant increase in fruit $\mathrm{Cu}, \mathrm{Zn}$ and $\mathrm{Fe}$ content in all treatments comparing with control in both seasons of study. The highest level of $\mathrm{Cu}$ was associated with mixed nutrients following copper sulphate at $0.02 \%$ and sequestrated Iron at $0.06 \%$. As for $\mathrm{Zn}$ content the highest value associated with mixed nutrients followed sequestrated Iron at $0.06 \%$ and sequestrated zinc at $0.04 \%$ in both seasons. Concerning Fe content data in Table 6 indicated that mixed nutrients, sequestrated iron at $0.06 \%$ and copper sulphate at $0.02 \%$ were increased significantly Fe content compared to control, in both seasons. The highest value recorded by mixed nutrients (101 and $102 \mathrm{ppm}$ ).

Amer et al. (2010) reported that soil applied micronutrients increased their concentration in leaves and fruits more than foliar application except $\mathrm{Cu}$. These results agreed with El-Sisy (2011) who reported that there were a significant increase in fruit $\mathrm{Fe}, \mathrm{Mn}$ and $\mathrm{Zn}$ comparing with control in both seasons of study. On the other hand, El-Gazzar et al. (1979) who reported that fruits of grapes were not significantly affected by either soil or foliar application of $\mathrm{FeSO}_{4}$ and $\mathrm{ZnSO}_{4}$.

Total sugar, reducing and non-reducing sugars (\%): The effect of foliar application of some nutrients on fruit content of total sugars $\%$ is tabulated in Table 7. Data relieved that some treatments increased fruit content of total sugars compared with control. The highest percentage was induced from mixed nutrients in both seasons $(10.00$ and $10.16 \%)$ respectively.

Effect of potassium sulphate at $0.1 \%$ followed without significant differences between them in both seasons, then sequestrated Zinc at $0.4 \%$ followed with significant differences between them and to control in both seasons.

Concerning reducing sugars percentage, data in Table 7 indicated that all treatments significantly increased reducing sugars $\%$ compared to control in both seasons except, copper sulphate at $0.02 \%$. Mixed nutrients and potassium at $0.1 \%$ gave the highest percentage and followed by sequestrated Iron at $0.06 \%$ in both seasons.

Data in Table 7 showed that, in the first season all treatments except copper sulphate at $0.02 \%$ and sequestrated Iron at $0.06 \%$ cleared significant increase in fruit non reducing sugars \% compared to control. The highest percentage recorded at mixed nutrients, then sequestrated zinc at $0.04 \%$ followed. The lowest percentage was recorded at sequestrated Iron at $0.06 \%$. In the second season, data indicated that all treatments increased the percentage of non reducing sugars in fruit compared with control. The highest value was recorded at mixed nutrients and followed by sequestrated Iron at $0.06 \%$, while the lowest value induced at control.

Egypt. J. Hort. Vol. 40, No.2 (2013) 
TABLE 7. Effect of foliar application of some nutrients on some fruit quality of "LeConte" pear trees during 2010 and 2011 seasons.

\begin{tabular}{|l|c|c|c|c|c|c|}
\hline \multirow{2}{*}{ Treatments } & \multicolumn{2}{c|}{$\begin{array}{c}\text { Total sugars } \\
(\%)\end{array}$} & \multicolumn{2}{c|}{$\begin{array}{c}\text { Reducing } \\
\text { sugars (\%) } \\
(\%)\end{array}$} & \multicolumn{2}{c|}{$\begin{array}{c}\text { Non-reducing } \\
\text { sugars (\%) }\end{array}$} \\
\cline { 2 - 8 } & $\mathbf{2 0 1 0}$ & $\mathbf{2 0 1 1}$ & $\mathbf{2 0 1 0}$ & $\mathbf{2 0 1 1}$ & $\mathbf{2 0 1 0}$ & $\mathbf{2 0 1 1}$ \\
\hline Control (untreated trees) & 8.23 & 8.29 & 5.93 & 5.94 & 2.31 & 2.35 \\
\hline Potassium sulphate at 0.1\% & 9.59 & 9.84 & 7.13 & 7.35 & 2.46 & 2.49 \\
\hline Copper sulphate at 0.02\% & 8.46 & 8.50 & 6.21 & 6.02 & 2.25 & 2.48 \\
\hline Sequestrated zinc at 0.04\% & 8.94 & 8.72 & 6.43 & 6.39 & 2.51 & 2.39 \\
\hline Sequestrated iron at $0.06 \%$ & 8.67 & 8.65 & 6.80 & 6.43 & 1.89 & 2.55 \\
\hline Mixed nutrients & 10.00 & 10.16 & 7.17 & 7.53 & 2.84 & 2.63 \\
\hline L.S.D. at 0.05 & 0.46 & 0.39 & 0.35 & 0.32 & 0.02 & 0.04 \\
\hline
\end{tabular}

The data of this study are partially in line with Dahsham and Aly (1986) and El-Sisy (2011) on guava fruits, Mohamed and Ahmed (1991) and El-Seginy et al. (2003) on apple.

In plants, zinc plays a key role as structural constituent or regulatory CoFactor of a wide range of different enzymes and proteins in many important biochemical pathways and these are mainly concerned with carbohydrate metabolism both in photosynthesis and in the conversion of sugars to starch, protein metabolism, auxin (growth regulator) metabolism, pollen formation, the maintenance of the integrity of biological membranes, the resistance to infection by certain pathogen (Alloway, 2008).

The present data showed a positive effect (mostly significant) of the studied treatments on the shoot length and fruit yield and juice total sugars. However, data illustrated in Fig. $1 \& 2$ indicate high positive correlation coefficient and regression between shoot length (Independent factor) as well as all of fruit yield and juice total sugars (Dependent Factors) through the two studied seasons.

\section{Conclusion}

The results in the present research strongly provide that foliar application of "Le Cont" pear trees with single and mixture of chelated or sulphate $(\mathrm{K}, \mathrm{Cu}, \mathrm{Zn}$ and $\mathrm{Fe}$ ) at the named concentrations (applied three times during growing season starting immediately after fruit set and at 21 days intervals) cleared that mixed nutrients were the best treatment for enhancing vegetative growth, leaf area, leaf elements content, yield, fruit weight and fruit quality. 

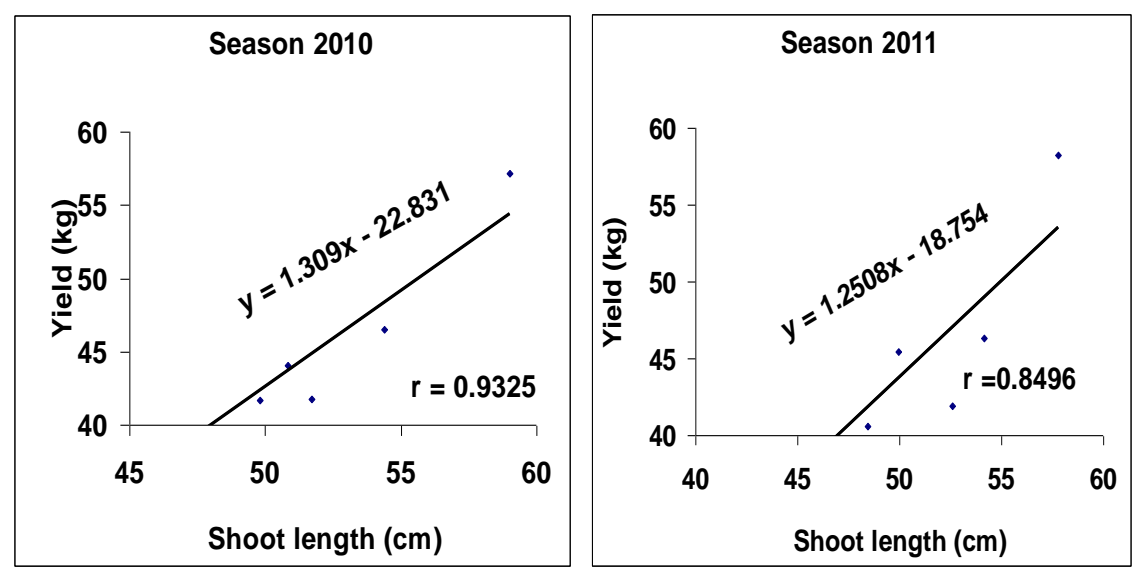

Fig. 1. Relationship between shoot length $(\mathrm{cm})$ and yield $(\mathrm{kg})$.
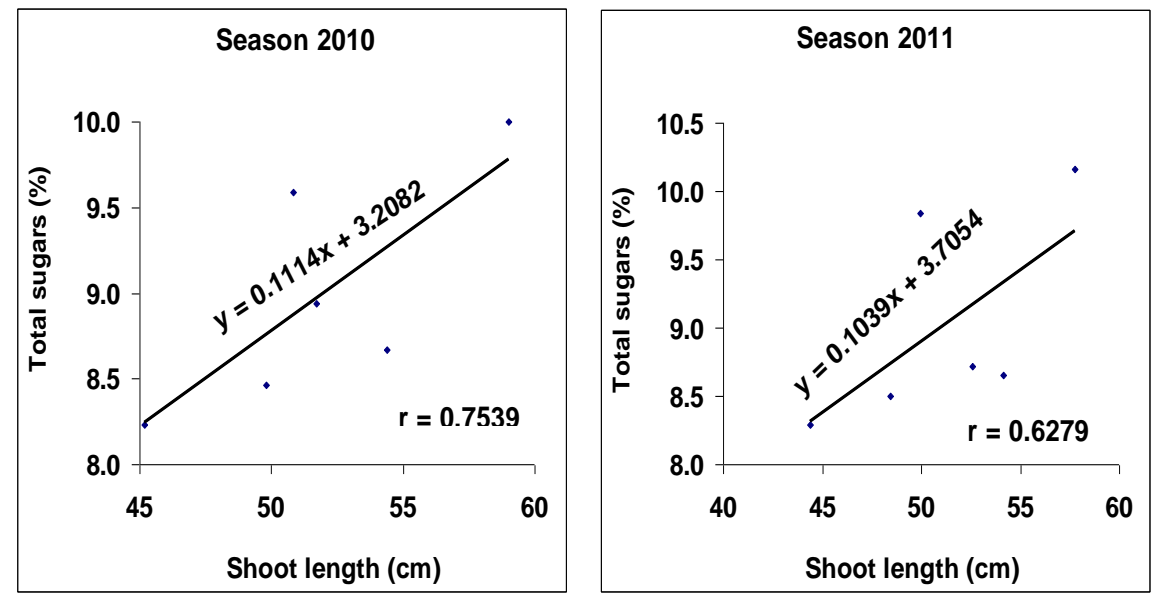

Fig. 2. Relationship between shoot length (cm) and total sugars (\%).

\section{References}

Abd-Ella, E.E.K. and Waffaa, A.A.Z. El-Sisy (2006) Effect of foliar application of gibberellic acid and micronutrients on leaf mineral content, fruit set, yield and fruit quality of "Sultani" fig trees. J. Adv. Agric. Res. Alex. J. Agric. Res., 31 (1), 25- 37.

Ahmed, F.F., Ragab, M.A., Ahmed, A.A. and Mansour, A.F.M. (1997) Efficiency of spraying Boron, Zinc, Potassium and Sulphate as affected with application of urea for "Anna" apple trees (Malus domestica L.) Egypt. J. Hort., 24 (1), 75-90. 
Akay, A. (2011) Effect of zinc fertilizer applications on yield and element contents of some registered chickpeas varieties. African Journal of Biotechnology, 10, 1309013096.

Alloway, B.J. (2008) Zinc in Soils and Crop Nutrition, $2^{\text {nd }}$ ed., published by IZA and IFA. Brussels, Belgium and Paris, France.

Amberger, A. (1982) Micronutrient and other iron problems in Egypt. Journal plant nutrition, 5 (4-7), 967-968.

Amer, M.A., Afaf, M.A. Yousif and Gowad, M. (2010) Effect of different levels of soil and foliars application of Micronutrients fertilizer on "Toffahy and Balahy Indian" ber trees (Zizyphus mauritiana lamk) grown in sandy soil. Alexandria Science Exchange Journal, 31(1), January-March. 25-37.

Association of Official Agricultural Chemists (1992) Official Methods of analysis Published by A.O.A.C., Benjamin Franklin Station, Washington DC, USA.

Awad, S.M. and Atawia, A.R. (1995) Effect of foliar sprays some Micronutrients on “ Le Conte" pear trees.1- tree growth, flowering and leaf mineral contents. Annual Agric. Sci. Cairo, 40(1), 359-397.

Chekan, A.S. (1988) Effects of chloro-chline Chloride and macro and microelements on the growth and productivity of young spur type apple trees. Referativnyi Zhurmal, 2. 55. 655, Hort. Abst., 58 (8), 684.

Chuntanaperb, N. and Cummings, G. (1981) Seasonal trends in concentration of nitrogen, phosphorus, potassium, calcium and magnesium in leaf portions of apple, blueberry, grape and peach. J. Amer. Soc. Hort. Sci., 105(6), 933.

Dahsham, D.I. and Ozoris, M. Ali (1986). Response of guava trees grown on sandy soil to macro and micro - nutrients application. Zagazig Jour. Agric. Res., 13 (1),1986.

Datir, R.B., Apparao, B.J. and Laware, S.L. (2012) Application of amino acid chelated micronutrients for enhancing growth and productivity in chili (Capsicum annum L.) Plant Sciences Feed, 2(7), 100-105.

Delcheva, S. and Makariev, Z. (1982) Studies on the causes of die-back in apple and pear trees in the Razlong region. Gradinarskai-Lozarska Nauka, 19 (8), 43-49. (Hort Abst. 53:4814).

Dubois, M., Cilles, K.A., Hamilton, J.K., Rober, P.A. and Smith, F. (1956) Colorimetric method for determination of sugar and related substances. Anal. Chem.., 28, 350-356.

El-Gazzar, A.M., Keleg, F.M. and Sabbah, S.M. (1979) Effect of foliar applications of chelated iron, zinc and manganese on yield, fruit quality, and concentrations of some nutrients in leaves of "Thompson Seedless" grapes. Alex. J. Agric. Res., 27 (1), $27-38$.

El-Khawaga, A.S. (2007) Improving growth and productivity of "Manzanillo" olive trees with foliar application of some nutrients and girdling under sandy soil. Journal of Applied Science Research, 3(9), 818-822. 
El-Safty, M.A., Elham, A., El-Menshawi and Abd-Allah, M.A. (1998) Effect of spray applications of GA and micronutrients on fruiting and leaf chemical composition of "Washington navel" orange trees. J. Agric. Res. Tanta Univ., 24 (2), 208-214.

El-Seginy, Amal M. and Khalil, B.M. (2000) Effect of spraying some nutrients and gibberellic acid on leaf mineral content, fruit characters and yield of "Le Conte" pear trees. J. Agric. Sci. Mansoura Univ., 25 (6), 3529- 3539.

El-Seginy, Amal M., Malaka, S.M. Naiema, Abd El- Messeih, W.M. and Eliwa, G.I. (2003) Effect of foliar spray of some micro nutrients and Gibberellins on leaf mineral content, fruit set, yield and fruit quality of "Anna" apple trees. Alex. J. Agric. Res., 48 (3), 137- 143

El-Shazly, S.M. (1999) Response of "Anna" apple trees to foliar sprays of chelated iron, manganese and zinc. J. Agric. Sci. Mansoura Univ., 24 (12), 7595- 7591.

El-Shobaky, M.A., Enas, S., Abbas and Hanaa, A., El- Helw (2001) Effect of microelements spray on leaves mineral content, yield, and quality and storage ability of "Ruby Seedless" grapes. J. Agric. Sci. Mansoura Univ., 26 (3),1721- 1733.

El-Sisy, Waffaa A.A.Z. (2011) Response of guava Cv. "Secdy Montakhab" trees to micro - nutrients and its effect on fruit quality. Alexandria Science Exchange Journal. 32(4), October- December. 489-497.

Gobara, A.A. (1998) Response of "Le Conte" pear trees of foliar applications of some nutrients. Egypt. J. Hort., 25(1), 55-70.

Kabeel, H., Mokhter, H. and Aly, M.M. (1998) Effect of foliar application of different macro and micro nutrients on yield, fruit quality and mineral composition of "Le Conte" pear. J. Agric. Sci. Mansoura Univ., 23 (7), 3317- 3325.

Kilany, A.A. and Kilany, Omaima A. (1991) Effect of Potassium and Boron nutrients on growth, yield and fruit quality of "Anna" apple trees. Bull. Fac. Agric. Cairo, Univ. 42(2), (April) 415-428.

Ljones, B. (1974) Long term effect of potassium in an experiment with apple trees. Melidinger Fra Norgas Landbruk Shogoskole, 53 (9),16. (Hort. Abst. 45:6301).

Larue, J.H. and Johnson, R.S. (1989) Peaches, Plums and Nectarines growing and handling for fresh market Copyright the Regent of the Univ. of Calif., Division of Agric. and Ntural Resources Pub., 3331,74-81.

Magness, J.R. and Taylor, G.P. (1925) An improved type pressure tester for the determination of fruit maturity. U.S. Dept. Agric. Circ., 350, 8p.

Malik, C.P. and Singh, M.B. (1980) Plant Enzymology and Histoenzymology. A textmanual. Kalyani. Publishers, New Delhi.

Mantinger, H. (1983) Interim results of an 11- year- manorial experiment obstbau weinbau, 20 (3), 94- 96. (Hort Abst. 54: 5684).

Egypt. J. Hort. Vol. 40, No.2 (2013) 
Marschner, H. (1995) Mineral Nutrition of Higher Plants, $2^{\text {nd }}$ ed. Academic press, London. pp. 330-355.

Mohamed, M.A. and Ahmed, F.F. (1991) Yield and quality of "Anna" apple cultivar fruits as affected by application of copper, zinc and iron nutrients. Annals of Agric. Sci. Moshtohor, 29 (1), 513- 526.

Naiema, Malaka S.M. (2006) Effect of foliar and soil magnesium sulphate fertilizer on vegetative growth, leaf mineral and chlorophyll content, fruit set, yield and fruit quality of "Le Conte" pear trees. Alex. J. Agric. Res., 51 (3), 73- 83.

Nijjar, G.S. (1985) Nutrition of Fruit Trees. Published by MRS. Usha Raj Kumar for kalyani publishers, New Delhi. pp. 173- 270.

Outten, C.E. and O'Halloran, T.V. (2001) Femtomolar sensitivity of metalloregulatory proteins controlling zinc homeostasis, Science , 292, 2488-2492.

Pandey, N., Pathak, G. and Sharma, C.P. (2006) Zinc is critically required for pollen function and fertilization in lentil. Journal of Trace elements in Medicine and Biology, 20, 89-96.

Pedler, J.F., Parker, D.R. and Crowley, D.E. (2000) Zinc deficiency-induced phytosiderophore release by the Triticaceae is not consistently expressed in solution culture. Planta, 211, $120-126$.

Price, G.A. (1970) Molecular Approach to Plant Physiological. MC. Graw- ill, p. 398.

Raese, J. T. and Parish, C. L. (1984) Mineral analysis and performance of chloratic pear trees sprayed or injected with iron. J. plant nutrition 7(1-5), 243-249. Wanatchee, W. A., U. S. A.

Raese, J.T., Parish, C.L. and Staiff, D.C. (1986) Nutrition of apple and pear trees with foliar sprays, trunk injections or soil applications of iron compounds. J. Plant Nutrition, 9 (3-7), 987- 999, Wenatchee, W. A., U.S.A.

Reimer, F.C. (1950) Development of blight resistant of French pear rootstocks. Stat. Bull. Gre. Agr. Exp. Sta., 24, 485.

Sarma, R. and Bhattacharyya, R.K. (1989) Effect of foliar nutration of zinc on the nutrient concentration of guava leaves. South Indian Horticulture, 37 (6) 323-325 (En, 3 ref.) Department of Hourticulture, Assam Agriculture University, Jorhat- 12, Assam, India. \{Hort. Abst. V.(61) No.5(4442)\}.

Sayed, R.M., Mohamed, G. and Maryam, R. (2013) Zinc (Zn) importance for crop production. Inter. J. Agronomy \& Plant Production, 4(1), 64-68.

Semenovich, G.I. and Salmina, T.A. (1979) Utilization of potassium fertilizers for improving the growth of apple trees on newly cultivated chernozem. Selektsiya I Agrotekhn. Vyrashchivanya plov. I Yagodn. Kul” tur V sredn. Povolzh"e. Kuibyshev, USSR, 87- 97. (Hort. Abst. 50:4985). 
Smith, P.F. (1957) Studies on the growth of citrus seedlings with different nutrient solutions. Plant physiology, 32,11- 15.

Snedecor, G.W. and Cochran, W.G. (1990) Statistical Methods. $7^{\text {th }}$ ed, The Iowa State Univ. Press. Ames., Iowa, U.S.A., p. 593.

Sourour, M.M. (1992) Response of "Anna" apple trees to different methods and forms of iron application. Alex. J. Agric. Res., 37 (2), 191- 204.

Swietlik, D. (2002) Zinc nutrition of fruit trees by foliar sprays. Acta. Hort. 594. Alex. J. Agric. Res., 32 (4), 489- 497.

Taiz, L. and Zieger, E. (1998) Plant Physiology, $2^{\text {nd }}$ ed., Sinauer Ass., Inc. Pub. USA.

Ubavic, M., Kastori, R., Petrovis, N., Vereb, A., Nikolic, B. and Babic, N. (1984) Efficiency of some Fe- chelate preparations for elimination Fe- chlorosis in apple. $J$. Hort. Sci., 59 (3), 162- 168.

Vitosh, M.L., Warncke, D.D. and Lucas, R.E. (1994) Zinc determine of crop and soil. Michigan State University Extension. International J. of Agronomy and plant production, 4(1), 64-68.

Westwood, M.N. (1993) Temperate- Zone Pomology (Physiology and Culture), $3^{\text {rd }}$ ed. Timber Press Inc., Portland, Oregon, USA, 488p.

Wilde, S., Corey, R.B., Layer, G.B. and Voigt, G.K. (1985) "Soil and plant analysis for tree culture". $3^{\text {rd }}$ ed. Oxford and IBM. Publishing Co., New Delhi. pp.93-106.

Yogaratnam, N. and Johnson, D.S. (1982) The application of foliar sprays containing nitrogen, magnesium, zinc and boron on apple trees. II. Effect on the mineral composition and quality of the fruit. J. Hort. Sci., 57(2),159-164.

(Received 20/ 8/2013

accepted $25 / 11 / 2013$

Egypt. J. Hort. Vol. 40, No.2 (2013) 


\section{تأثير رش بعض المغذيات الورقية على نمو أشجار الكمثرى صنف "ليكونت" تحت ظروف التربة الجيرية الورغية}

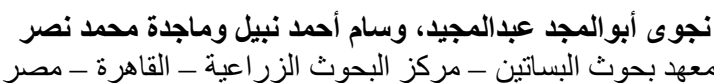

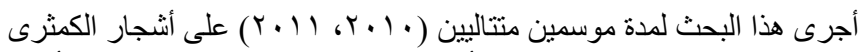

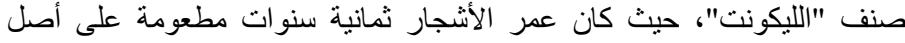

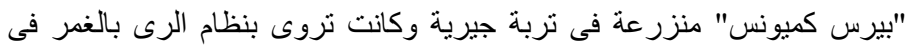

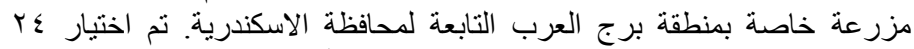

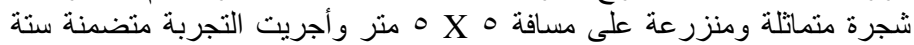

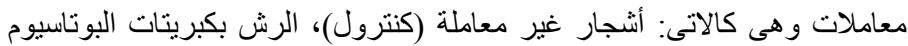

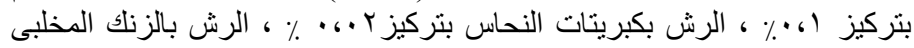

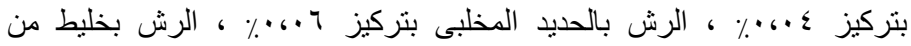

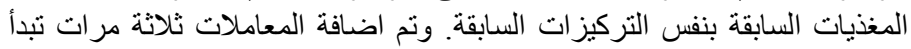

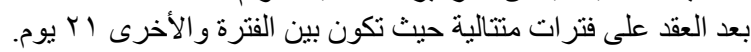

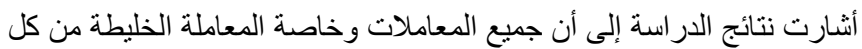

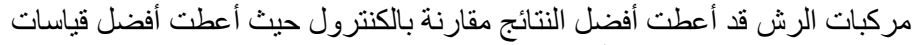

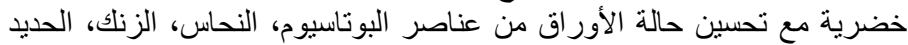

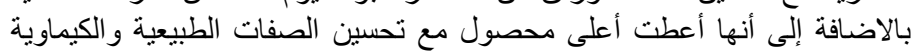
للثمار. 